原 著

\title{
高齢者の脳主幹動脈閉塞症に対する血管内再開通療法
}

\author{
佐藤允之 ${ }^{1)}$ 天野達雄 ${ }^{1)}$ 早川幹人 ${ }^{2)}$ 松丸祐司 ${ }^{1)}$
}

\section{Acute revascularization by endovascular therapy for stroke in the very elderly}

\author{
Masayuki SATOU $^{1)}$ Tatsuo AMANO ${ }^{1)}$ Mikihito HAYAKAWA ${ }^{2)} \quad$ Yuuzi MATSUMARU $^{1)}$ \\ ${ }^{1)}$ Department of Neuroendovascular Therapy, Toranomon Hospital \\ ${ }^{2}$ Department of Cerebrovascular Medicine, National Cerebral and Cardiovascular Center Hospital
}

\begin{abstract}
Objective: We retrospectively analyzed the efficacy of interventional revascularization therapy in very elderly patients with acute stroke.

Methods: Patients undergoing acute revascularization therapy between July 2010 and January 2013 in our hospital were retrospectively analyzed. Age, sex, infarcted side, risk factors for ischemic stroke, National Institute of Health Stroke Scale (NIHSS) score, Alberta Stroke Program Early CT score-diffusion weighted imaging (ASPECTS-DWI) score, types of infarction, occlusion with or without intravenous administration of tissue-type plasminogen activator (IV-tPA), devices used, time course, effectiveness of revascularization (Thrombolysis in Cerebral Infarction; TICI 2a or more than TICI $2 b$ ), complications, and functional outcome were compared among elderly ( $>75$ years/old; y/o) and nonelderly ( $\leq 75 \mathrm{y} / \mathrm{o})$ patients.

Results: Combination therapy with IV-tPA was performed for 21 (46\%) patients. The median NIHSS score upon arrival at the hospital was 18 and the median ASPECTS-DWI score before treatment was 7. There was no difference in the puncture to revascularization time between the two groups. We achieved an effective revascularization for 30 patients ( 9 elderly, 21 non-elderly). Other than age, there was no significant difference in any of the patient characteristics between the two groups. Major complications were symptomatic cerebral hemorrhage in 1 patient of the non-elderly group and asymptomatic subarachnoid hemorrhage in 5 elderly and 9 non-elderly patients. Good functional recovery (modified Rankin Scale; $\mathrm{mRS} \leq 3)$ at discharge was seen in 7 elderly $(47 \%)$ and $13(42 \%)$ non-elderly patients. There was no significant difference in the rate of 0-3 mRS at hospital discharge. After 90 days, 4 elderly (26\%) and $3(10 \%)$ nonelderly patients had died. The recanalization rate was equivalent between the non-elderly and elderly.

Conclusions: Acute revascularization by endovascular therapy has the potential to improve functional prognosis in the very elderly following stroke events.
\end{abstract}

Key words

acute ischemic stroke, endovascular revascularization therapy, elderly people

1)虎の門病院 脳神経血管内治療科

2) 国立循環器病研究センター 脳血管内科

<連絡先：佐藤允之 干 105-8470 東京都港区虎の門 2-2-2 E-mail: marchin16@yahoo.co.jp >

(Received December 3, 2013 : Accepted May 12, 2014)

doi: 10.5797/jnet.or.13047

緒 言

2010 年 7 月から Merci Retrieval system (Concentric Medical, Mountain View, CA, USA) が導入され, 急性 期脳梗塞に対する血管内再開通療法が本格的に施行 されるようになった，今回，我々は高齢者に対する
血管内治療による急性期血行再建の有効性と問題点 を検討した。

当院の急性期再開通療法の適応

発症 4.5 時間以内の急性期脳梗塞に関しては, ア ルテプラーゼ (tPA) 静注療法を禁忌事項がなければ行 
う. tPA 投与 1 時間後に症状の改善がなく, 脳主幹 動脈に再開通が得られてないと判断する場合には脳 血管造影を行い，さらに主幹動脈閉塞を認める場合 には，引き続き血管内治療を検討する，血管内再開 通療法の適応は, clinical-diffusion mismatch があるも のとする. Clinical-diffusion mismatch は Alberta Stroke Program Early CT score-diffusion weighted imaging (ASPECTS-DWI) 5 点以上か $\supset$ National Institute of Health Stroke Scale (NIHSS) 8 点以上の症例と定義し ている。ただし，NIHSS 7 点以下でも，脳主幹動脈 閉塞症があり, 高次脳機能障害, 症状の進行や動摇 がある場合には適応としている。急性期血行再建 は，原則として 8 時間以内の症例に適応することと されているが，当院では 8 時間を経過した症例でも clinical-diffusion mismatch があれば適応と考え，時間 経過は制限していない。また，年齢制限も設けてい ない.

\section{対象と方法}

2010 年 7 月から 2013 年 1 月までの期間に, 当科 で治療を行った急性期脳主幹動脈閉塞症による脳梗 塞に拈いて, 8 時間以内に血管内再開通療法を開始 した 46 人について, 高齢者群 (75 歳以上) と非高齢 者群 (75 歳未満)に分けて後方視的に比較検討を行っ た。検討項目は，背景因子として性別，高血圧，高 脂血症, 糖尿病, 喫煙, 飲酒, 脳梗塞 - 脳出血の既 往, 心筋梗塞の既往, 悪性腫瘍, 発症前内服状況 (抗 凝固薬・抗血小板剤), 病側 (左側), 来院時 NIHSS score, 治療前 ASPECTS-DWI, 脳梗塞病型 (心原性塞 栓症・アテローム血栓性，その他), 閉塞血管(内頝 動脈, 中大脳動脈 M1 部, 中大脳動脈 M2 部, 椎骨 動脈 - 脳底動脈系), 治療方法として Merci Retrieval system, Penumbra system (Penumbra, Alameda, CA, USA）の使用頻度, tPA 静注療法併用の有無, デバ イス使用数(単独または複数), 時間経過として発症 から再開通(または手技終了)まで, 穿刺から再開通 （または手技終了）まで，有効再開通(Thrombolysis in Cerebral Infarction; TICI 2a 以上またはTICI 2b以上 ${ }^{1)}$, 合併症 (症候性出血, 無症候性くも膜下出血) の有無, 退院時modified Rankin Scale (mRS) でmRS 0〜2または mRS 0 3, 90 日後の mRS 6 (死亡) について検討し た。統計学的検討には, SPSS ver.19(IBM, Armonk, NY, USA）を用いて行った。連続変数については $\mathrm{t}$ 検
定を行い, カテゴリー変数に関してはカイ 2 乗検定 を行い，P<0.05を有意差ありと定義した。

\section{結 果}

背景因子，危険因子，来院時評価，病型，閉塞血 管を Table 1 に示す. 高齢者群は 15 人(平均年齢 $80.9 \pm 3.8$ 歳), 非高齢者群は 31 人 (平均年齢 $61.6 \pm 10.7$ 歳)であった。左側病変は非高齢者で有意に多かった (40\% vs $77 \%, P<0.05)$ ， その他の背景因子について は，群間に差異を認めなかった。来院時 NIHSS score の中央值は全体で 18 点, 治療前 ASPECTS-DWI score の中央値は全体では 7 点で, 群間に差異を認めな かった。病型と閉塞血管に関しても，群間に差異を 認めなかった。

治療内容 (方法, 時間経過, 有効再開通), 合併 症，機能予後について Table 2 に示す，治療方法 は, tPA 静注療法併用は高齢者群 7 人 $(47 \%)$ で非高 齢者群 14 人 $(45 \%)$ とほほ同じ割合であった。使用機 材に関しては，全体では Merci Retrieval system 23 人

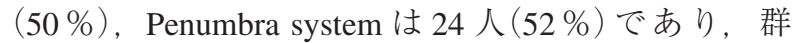
間で差異を認めなかった。デバイスは単独使用が 25 人 $(54 \%)$ と複数使用が 22 人 $(48 \%)$ であった。時間 経過に関しては，発症から再開通(手技終了)までの 平均所要時間は, 全体で $348 \pm 101$ 分, 高齢者群では $336 \pm 110$ 分, 非高齢者群では354 97 分であり群間に 差異を認めなかった。 また，穿刺から再開通(手技 終了)までの時間は全体で平均 $118 \pm 58$ 分, 高齢者群 では $120 \pm 50$ 分, 非高齢者群では $117 \pm 62$ 分であり, 群間で差異を認めなかった。有効再開通は TICI 2a 以上は高齢者群で 13 人 $(87 \%)$, 非高齢者群で 26 人 (84\%)であり, TICI 2b 以上は高齢者群 9 人 $(60 \%)$, 非高齢者群 21 人 $(68 \%)$ に認め, ほほ同等の再開通 率であった。出血性合併症に関しては，症候性出血 を非高齢者群の 1 人 $(3 \%)$ のみに認めた。無症候性 のくも膜下出血は全体で 14 人 $(30 \%)$ に認め, 高齢 者群では 5 人 $(33 \%)$, 非高齢者群 9 人 $(29 \%)$ と群間 に差異を認めなかった。機能予後として退院時 mRS は, mRS 0 2 では全体で 13 人 $(28 \%)$, 高齢者群 3 人 $(20 \%)$, 非高齢者群 10 人 $(32 \%)$ であり, mRS 0 3 では全体で 20 人 $(43 \%)$, 高齢者群 7 人 $(47 \%)$, 非 高齢者群 13 人 $(42 \%)$ とそれぞれ群間に差異は認めな かった，有効再開通後における退院時機能予後につ いて, TICI $2 b$ 以上の有効再開通が得られても，高齢 
Table 1 Characteristics of patients undergoing acute recanalization therapy in our hospital

\begin{tabular}{|c|c|c|c|c|}
\hline & $\underset{(\mathrm{n}=46)}{\text { All }}$ & $\begin{array}{l}\text { Elderly } \\
(n=15)\end{array}$ & $\begin{array}{l}\text { Non-elderly } \\
\quad(\mathrm{n}=31)\end{array}$ & $\mathrm{p}$ value \\
\hline \multicolumn{5}{|l|}{ Background } \\
\hline Age & $68.0 \pm 12.8$ & $80.9 \pm 3.8$ & $61.6 \pm 10.7$ & $\mathrm{P}<0.001$ \\
\hline Male (\%) & $35(76)$ & $9(60)$ & $26(84)$ & NS \\
\hline Infarcted side (left) (\%) & $30(65)$ & $6(40)$ & $24(77)$ & $\mathrm{P}<0.05$ \\
\hline \multicolumn{5}{|l|}{ Risk factor $(\%)$} \\
\hline Hypertension & $25(54)$ & $6(40)$ & $19(61)$ & NS \\
\hline Dyslipidemia & $6(13)$ & $1(7)$ & $5(16)$ & NS \\
\hline Diabetes & $6(13)$ & $2(13)$ & $4(13)$ & NS \\
\hline Smoking & $7(15)$ & $2(13)$ & $5(16)$ & NS \\
\hline Drinking alchohol & $7(15)$ & $2(13)$ & $5(16)$ & NS \\
\hline Old cerebral infafrction & $7(15)$ & $2(13)$ & $5(16)$ & NS \\
\hline Old cerebral hemorrhage & 0 & 0 & 0 & NS \\
\hline Old cardiac infarction & $5(11)$ & $2(13)$ & $3(10)$ & NS \\
\hline Malignant tumor & $8(17)$ & $2(13)$ & $6(19)$ & NS \\
\hline Anti-coagulation drugs & $5(11)$ & $2(13)$ & $3(10)$ & NS \\
\hline Anti-platelete drugs & $11(24)$ & $2(13)$ & $9(29)$ & NS \\
\hline \multicolumn{5}{|l|}{ Evaluation at hospital alival } \\
\hline NIHSS score medium (range) & $18(5-37)$ & $17(8-27)$ & $19(5-37)$ & NS \\
\hline ASPECTS-DWI medium (range) & $7(2-11)$ & $8(5-10)$ & $7(2-11)$ & NS \\
\hline \multicolumn{5}{|l|}{ Type of infarction $(\%)$} \\
\hline Cardiac embolism & $29(63)$ & $10(67)$ & $19(61)$ & NS \\
\hline Atherothrombotic & $7(15)$ & $3(20)$ & $4(13)$ & NS \\
\hline Others & $10(22)$ & $2(13)$ & $8(26)$ & NS \\
\hline \multicolumn{5}{|l|}{ Occluded vessel (\%) } \\
\hline ICA & $12(26)$ & $3(20)$ & $9(29)$ & NS \\
\hline MCA M1 portion & $22(48)$ & $8(53)$ & $14(45)$ & NS \\
\hline MCA M2 portion & $10(22)$ & $4(27)$ & $6(19)$ & NS \\
\hline VA-BA & $2(4)$ & 0 & $2(6)$ & NS \\
\hline
\end{tabular}

NIHSS; National Institute of Health Stroke Scale, ASPECTS; Alberta Stroke Program Early CT score, DWI; diffusion weighted imaging, ICA; internal carotid artery, MCA; middle cerebral artery, VA-BA; vertebro-basilar, NS; not significant

者群では非高齢者群に比べて mRS 0２の割合が低 い傾向があった $(13 \%$ vs $32 \%, \mathrm{P}=0.17)$ 。また, mRS 0〜2の割合は TICI 2a の再開通を加えても，高齢者 群で 1 人増加するのみであった. 90 日後の mRS 6 (死亡) は全体で 7 人 $(15 \%)$, 高齢者群 4 人 $(26 \%)$, 非高齢者群 3 人 $(10 \%)$ であり, 高齢者群で多い傾向 にあったが群間で有意差を認めなかった。死亡原因 は，高齢者群で脳梗塞関連の死亡 1 人，誤嚥性肺炎 が 1 人，心疾患が 2 人であった。非高齢者では，が ん死亡 2 人, 肺塞栓症 1 人であった.

\section{考 察}

脳主幹動脈閉塞に対する血管内再開通療法は, 再 開通率が高く機能予後を改善するという報告がある
一方 ${ }^{2-4)}$ ，最近では否定的な報告も散見される Һ, $^{5,6}$ ま た，高齢者に対する血行再建の成績に関しても，死 亡率が上がり，良好な成績を得にくいという報告が ある7)。過去の tPA 静注療法に打ける報告でも，高齢 は脳卒中後の機能予後不良と死亡に関する, 単独の 関連因子とされている ${ }^{8,9)}$.

今回の検討では，再開通率は高齢者群と非高齢者 群で全く差異を認めなかった. Merci/Multi Merciの プールデータによる高齢者群 (75 歳以上) の解析と 当院の高齢者群の成績を比較すると，機能予後は mRS 0 2 が $20 \%$ (3 カ月後) と 20\% (退院時), 死亡 率 (90日後) は $36 \%$ と $26 \%$ であり，高齢者に対する 血管内再開通療法による治療成績は既報と同等で

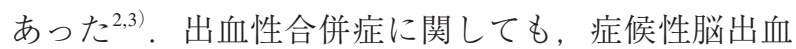


Table 2 Methods, time course, outcome and complications of acute recanalization therapy in our hospital

\begin{tabular}{|c|c|c|c|c|}
\hline & $\underset{(n=46)}{\text { All }}$ & $\begin{array}{l}\text { Elderly } \\
(n=15)\end{array}$ & $\begin{array}{l}\text { Non-elderly } \\
\quad(\mathrm{n}=31)\end{array}$ & $\mathrm{p}$ value \\
\hline \multicolumn{5}{|l|}{ Treatment (\%) } \\
\hline IV-tPA combined & $21(46)$ & $7(47)$ & $14(45)$ & NS \\
\hline Merci retrieval system & $23(50)$ & $8(53)$ & $15(48)$ & NS \\
\hline Penumbra reperfusion system & $24(52)$ & $8(53)$ & $16(52)$ & NS \\
\hline Single device & $25(54)$ & $11(67)$ & $14(45)$ & NS \\
\hline Multi devices & $22(48)$ & $5(33)$ & $17(55)$ & NS \\
\hline \multicolumn{5}{|l|}{ Time course minutes $( \pm \mathrm{SD})$} \\
\hline Onset-recanalization & $348 \pm 101$ & $336 \pm 110$ & $354 \pm 97$ & NS \\
\hline Puncture-recanalization & $118 \pm 58$ & $120 \pm 50$ & $117 \pm 62$ & NS \\
\hline \multicolumn{5}{|l|}{ Effective revasculization (\%) } \\
\hline TICI $2 \mathrm{a} \leq$ & $39(84)$ & $13(87)$ & $26(84)$ & NS \\
\hline TICI $2 b \leq$ & $30(65)$ & $9(60)$ & $21(68)$ & NS \\
\hline \multicolumn{5}{|l|}{ Complication (\%) } \\
\hline Symptomatic hemorrhage & $1(2)$ & 0 & $1(3)$ & NS \\
\hline A symptomatic SAH & $14(30)$ & $5(33)$ & $9(29)$ & NS \\
\hline \multicolumn{5}{|l|}{ Functional outcome (\%) } \\
\hline mRS 0-2 at hospital discharge & $13(28)$ & $3(20)$ & $10(32)$ & NS \\
\hline mRS $0-3$ at hospital discharge & $20(43)$ & $7(47)$ & $13(42)$ & NS \\
\hline mRS 6 after 90 days & $7(15)$ & $4(26)$ & $3(10)$ & NS \\
\hline
\end{tabular}

IV-tPA; intravenous tissue-type plasminogen activator, SD; standard deviation, TICI; Thrombolysis in Cerebral Infarction; SAH; subarachnoid hemorrhage, mRS; modified Rankin Scale, NS; not significant

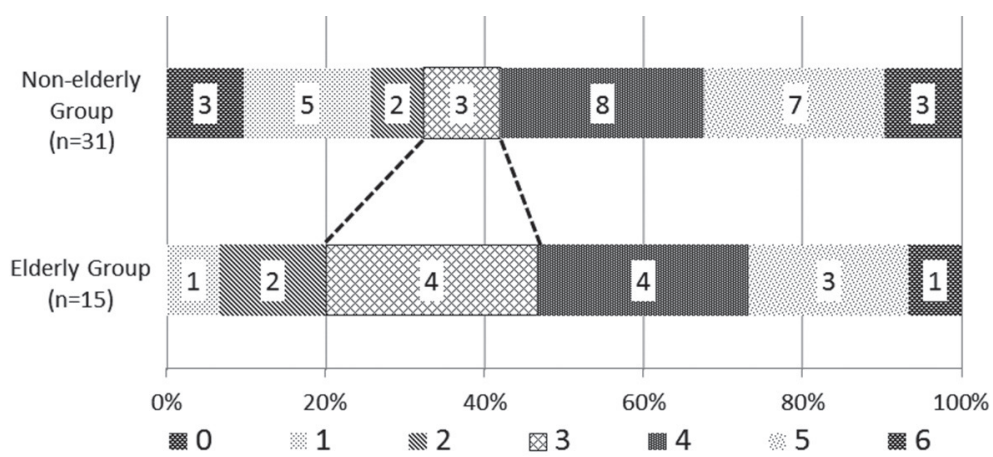

Fig. 1

Comparison of outcome at discharge in the elderly and non-elderly.

は非高齢者群の 1 人 $(2 \%)$ のみであり，無症候性の くも膜下出血も両群間で差異がなく, 既報と類似する 結果であった2).アルテプラーゼ静注療法無効例に対 する治療が 21 人 $(46 \%)$ 含まれていたが，それにより 出血性合併症が増加することは両群ともになかった。

手技に関する時間経過は, 両群とも 120 分前後で あり, 再開通率が変わらないことを考慮すると, 高 齢者で再開通が得られにくいわけではなく，かつ手 技時間が長くなるわけでもなかった。しかし，高龄 者群のなかには, 動脈硬化が強くアクセス困難な症
例の割合が高いので，治療前からの動脈硬化リスク 評価は治療の難しさを予測する上で重要である。使 用しているデバイス数(単独または複数)に関して は，高齢者の場合には，なるべくシンプルに単独デ バイスで治療を行い, 治療困難な場合には無理せず に撤退を検討する傾向にあると考えられた（45％vs $67 \%, \mathrm{P}=0.07$ ).

退院時機能予後に関して Fig. 1 に示す。高齢者群 では非高齢者群に比べて mRS 0〜2 の割合が低く, 再開通を得たとしても，退院直後の機能改善には貢 
献しにくい傾向があった。しかし，退院時 mRS 0〜 3 を良好な機能改善と考えた場合には，その割合は 両群間で同等であり，高齢者でも再開通が得られれ ば，機能改善が望めることを示唆している $(42 \%$ vs 47\%). また, 有効再開通後における退院時機能予後 について， TICI 2b 以上の有効再開通が得られても， 高齢者群では非高齢者群に比べて mRS 0２の割合 が低い傾向があった $(13 \%$ vs $32 \%, \mathrm{P}=0.17)$ 。 また， mRS 0〜2 の割合は TICI 2a の再開通を加えても，高 齢者群で 1 人増加するのみであった。このことは, 予後改善を狙うのであれば，高齢者であっても TICI $2 \mathrm{~b}$ 以上の再開通を目指さなくてはいけないことを示 唆している。また, 死亡率に関しては, 有意差は認 めないが高齢者群で非高齢者と比較すると若干高い (26\% vs 10\%, P=0.13). Loh らは Merci/Multi Merciの プールデータのサブ解析のなかで, 高齢者群で脳梗 塞関連死は多いが, 一方で, 生存者のみの解析では 高齢者も非高齢者も機能予後は同等であるという報 告をしている7). しかし, 当院における高齢者群の死 因に関しては，半数以上が脳梗塞関連以外の死因で あった。高齢者はもともと多くの基礎疾患を抱えて いることにも配慮する必要があると考えられた。

\section{結 論}

急性期脳主幹動脈閉塞症に対する血管内再開通療 法における高齢者の再開通率は非高齢者と同等であ る。また退院時 $\mathrm{mRS} 0$ ～ 3 の割合にも差異はなかっ た. 高齢者でも血管内再開通療法の適応を慎重に検 討し有効再開通が得られれば，機能予後の改善を期
待できる可能性がある。

本論文に関して, 開示すべき利益相反状態は存在 しない。

\section{文献}

1) Noser EA, Shaltoni HM, Hall CE, et al. Aggressive mechanical clot disruption: a safe adjunct to thrombolytic therapy in acute stroke? Stroke 2005; 36: 292-296.

2) Flint AC, Duckwiler GR, Budzik RF, et al. Mechanical thrombectomy of intracranial internal carotid occlusion: pooled results of the MERCI and Multi MERCI Part I trials. Stroke 2007; 38: 1274-1280.

3) The penumbra pivotal stroke trial. Safety and effectiveness of a new generation of mechanical devices for clot removal in intracranial large vessel occlusive disease. Stroke 2009; 40: 2761-2768.

4）坂井信幸, 植田敏浩, 早川幹人, 他. MERCIリトリー バーを用いた急性脳動脈再開通療法一我が国における 初期周術期成績 - . JNET 2011; 5: 23-31.

5) Broderick JP, Palesch YY, Demchuk AM, et al. Endovascular therapy after intravenous t-PA versus t-PA alone for stroke. $N$ Engl J Med 2013; 368: 893-903.

6) Ciccone A, Valvassori L, Nichelatti M, et al. Endovascular treatment for acute ischemic stroke. N Engl J Med 2013; 368: 904-913.

7) Loh Y, Kim D, Shi ZS, et al. Higher rates of mortality but not morbidity follow intracranial mechanical thrombectomy in the elderly. AJNR Am J Neuroradiol 2010; 31: 1181-1185.

8) Matsuo R, Kamouchi M, Ago T, et al. Thrombolytic therapy with intravenous recombinant tissue plasminogen activator in Japanese older patients with acute ischemic stroke: Fukuoka Stroke Registry. Geriatr Gerontol Int 2013.

9) Ford GA, Ahmed N, Azevedo E, et al. Intravenous alteplase for stroke in those older than 80 years old. Stroke 2010; 41: 2568-2574.

\section{要 旨}

JNET 8:70-74, 2014

【目的】高齢者に対する血管内再開通療法の有効性と問題点を検討した。【方法】2010 年 7 月から 2013 年 1 月までの 期間に，当科で急性期脳主幹動脈閉塞症による脳梗塞に対して，8 時間以内に血管内再開通療法を開始した 46 人に ついて, 高齢者群 (75 歳以上) と非高齢者群 (75 歳未満) に分けて後方視的に検討した.【結果】高齢者群は 15 人(平均 80.9 歳), 非高齢者群は 31 人 (平均 61.6 歳)であった。来院時 National Institute of Health Stroke Scale (NIHSS) score の 中央值は全体で 18 点, 治療前 Alberta Stroke Program Early CT score-diffusion weighted imaging (ASPECTS-DWI) score の中央值は全体では 7 点で, 群間に差異を認めなかった。穿刺から再開通(手技終了)までの時間は群間に差異 を認めず，再開通率もほぼ同等であった，症候性出血は非高齢者群の 1 人 $(2 \%)$ のみであった，機能予後は，退院時 modified Rankin Scale (mRS)0〜3に差異は認めなかった。90日後の mRS 6(死亡)も差異はなかった。【結論】急性 期脳主幹動脈閉塞症に対する血管内再開通療法に抢ける高齢者の再開通率は非高齢者と同等である。また退院時の 機能予後にも差異がなかった。 高齢者でも血管内再開通療法の適応を慎重に検討し, 有効再開通が得られれば, 機 能予後の改善を期待できる可能性がある. 